Counsellia: Jurnal Bimbingan dan Konseling

Volume 11 (1) 71 - 85 Mei 2021

ISSN: 2088-3072 (Print) / 2477-5886 (Online)

DOI: $10.25273 /$ counsellia.v11i18802

Available online at: http://e-journal.unipma.ac.id/index.php/JBK

\title{
Counseling Challenges in the New Normal : Inputs for Quality Guidance and Counseling Program
}

\author{
Gilbert S. Arrieta ${ }^{12}$, John Remwil B. Valeria ${ }^{1}$, Von Ryan U. Belen ${ }^{1}$ \\ ${ }^{1}$ Don Bosco Technical Institute-Makati City, Philippines \\ ${ }^{2}$ College of Graduate Studies and Teacher Education Research \\ Philippine Normal University-Manila
}

Corresponding email : arrieta.gs@ pnu.edu.ph

\begin{abstract}
In the Philippines, online learning delivery is the primary mode of learning with many private schools adapting it. Learning continuity plan was created and the Department of Education set the most essential learning competencies for school year 2020-2021. Counseling, a strong support in the welfare of the students, is needed to address the different concerns of the students. However, guidance counselors see a lot of challenges in providing counseling to students in an online environment. The study investigated on the experiences and challenges encountered by the guidance counselors specifically in providing counseling to students during the online teaching and learning. Using the phenomenological method, the researchers observed, interviewed, and conducted focusgroup discussion to seven guidance counselors in the basic education department. The study found out that mental health issues, feeling of isolation, voluminous requirements and unstable internet connection were the concerns of the students. In addressing them, they provided individual and group counseling, communicated with the parents, collaborated more closely with the class advisers, teachers, and academic heads, strengthened the homeroom and guidance period, and held mental health activities. Keywords : Counseling in the new normal, Mental health, Interventions, Collaboration with teachers.
\end{abstract}

\section{Received ; Accepted ; Published}

Citation: Arrieta S Gilbert, dkk, . (2021). Counseling Challenges in the New Normal : Inputs for Quality Guidance and Counseling Program. Counsellia: Jurnal Bimbingan dan Konseling, 11(1), 71 - 85. Doi.org/10.25273/counsellia.v11i18802

\section{(c) EY-NC-SA}

Copyright (C2021 Counsellia: Bimbingan dan Konseling

Published by Universitas PGRI Madiun. This work is licensed under the Creative Commons Attribution-NonCommercialShareAlike 4.0 International License

\section{INTRODUCTION}

When the unexpected happens, it compels people to adapt and make the necessary change in their lives. It brings one out of his comfort zone to find new ways of doing things. As they say, there is a silver lining in any challenge or difficulty that comes in one's life. The 
Covid-19 pandemic challenged the way things are done normally. The imposition of lockdown, physical distancing and other health protocols changed a lot of processes from business to education. Technology is optimized in business, government services, religious services, transportation, and education. After a temporary stop, different sectors resumed slowly and safely their operations because life has to continue even in a different way. One of the seriously affected sectors in society is education. Education leaders, teachers, and other stakeholders were in a quandary if classes will open in school year 2020-2021. In the Philippines, the government decided that classes will resume through online modality and other alternative learning systems. However, the readiness for online classes was a concern raised by students and teachers. A study showed that students forecasted that they might face issues, and the majority of the respondents are worried about internet connectivity in the area. It concluded that the majority of the students are not yet ready in a synchronous mode of delivery, and it is recommended that institutions in the Philippines may provide an additional way of instructional delivery to maintain academic excellence in challenging times (Pastor, 2020). Ironically, a similar study concluded that faculty and student readiness on online teaching and learning is determined by their competence, accessibility of ICT tool, preparedness, confidence in their ability to use technology, and exposure to e-learning materials. Hence, the university and in the broader scope, the Commission on Higher Education (CHED), may conduct series of training for teachers as a capacity building to equip them with knowledge and competencies on the use of flexible or blended learning. Further, a university-wide learning system may be designed, adopted, and implemented in case the Enhanced Community Quarantine will not be lifted for a longer period (Callo \& Yazon, 2020).

Prior to the opening of classes for 2020-2021, the Department of Education (DepEd) issued memoranda on the learning continuity plan (LCP) and most essential learning competencies (MELCs). Adhering to the two DepEd orders, a private sectarian school in the National Capital Region, started preparing for the incoming school year. Incidentally, the school was just in the first three weeks of Term 3 classes last school year (2019-2020) when the lockdown was imposed. Without any plan, teachers did their best to continue classes by using different online platforms. Supporting the teachers were the academic heads who checked and monitored them regularly about their needs and condition. Students were also followed up to know their situation and address their needs and concerns. Immediately at the end of school year 2019-2020, the academic heads and teachers discussed their experiences and assessed how classes were conducted in the remaining weeks of Term 3. Various challenges, issues and concerns were shared which became the basis in developing the learning continuity plan for school year 2020-2021. The LCP included online policies, synchronous and asynchronous classes, online activities, and other online services. One of the most important online services that is integral in teaching and learning is guidance and counseling. School counselors provide support to teachers by serving an important part of the complete team that addresses the educational goals and needs of their students. They can help plan classroom and group activities that meet the students' needs. Counselors gather and share resources with teachers to help the staff develop their skills in classroom management and teaching effectiveness. They also observe students in the classroom or playground and provide teachers assistance with their roles as guides.

During physical classes, one of the prevailing issues being dealt with by the guidance counselors is mental health-related concerns. Counseling students experiencing anxiety and depression by being physically present is evidently effective. The use of other forms of communication like mobile phones and internet is a supplemental means in keeping track of the students' situation. This is supported by a study that suggested offering online counseling, in addition to face-to-face services, could be an effective way for many 
university counseling centers to increase the utilization of their services and thus better serve their communities (Wong et al, 2018). However, with no face-to-face classes, providing counseling service to students became challenging with no data yet stating that counseling can be effective through online modality is effective for counseling. Online counseling programs are often viewed as less effective due to the lack of face-to-face interaction (Villarreal-Davis, Sartor, \& McLean, 2020). Knowing that more mental health concerns may emerge since the students are just at home and have less physical interaction with classmates and friends, the guidance counselors were groping in the dark on how to ensure that they are mentally, emotionally, and psychologically healthy. Guidance services particularly those related to counseling should continue to be provided to students who need more support and assistance considering the anticipated challenges of online learning. Moreover, professional school counselors provide needed and vital services to children and adolescents. Essential for the successful implementation of these needed services is to ensure that professional school counselors have the time and resources to perform one of the primary service that they are trained and competent to perform - counseling. As the modern school environment grows in complexity through high-stakes testing, state and federal standards, and district report cards and evaluations, professional school counselor roles are increasingly being re-directed to duties further away from the important mission of recognizing and addressing the mental health needs of students (Neyland-Brown, Francis \& Burns, 2019).

This study aims to find out the challenges encountered by guidance counselors in providing counseling and other related services to the students. It will also identify the issues and concerns experienced by students and how the guidance counselors handled the students. Through the experiences of the guidance counselors, new insights, activities, and strategies may have been conceived and implemented that will be needed to enhance the guidance and counseling program of the school.

The following are the questions that this study sought to be answered :

1. What preparations did the guidance counselors make for education in the new normal?

2. What are the challenges in counseling and interventions provided by the guidance counselors to students in an online environment?

3. Based on the findings, what inputs can be considered in enhancing the guidance and counseling program?

\section{METHODOLOGY}

\section{Method}

The method used in this study is phenomenology. It is an approach to qualitative research that focuses on the commonality of a lived experience within a particular group. The fundamental goal of the approach is to arrive at a description of the nature of the particular phenomenon (Creswell, 2014).

\section{Participants}

Participants in this study were seven guidance counselors from a private sectarian school in the National Capital Region, Philippines. The researchers were participant- observers and one of them is a member of the management team. Table 1 shows the profile of the participants/

Table 1. Profile of Participants

\begin{tabular}{c|c|c|c}
\hline Participants & Gender & Age & $\begin{array}{c}\text { Years of Experience as } \\
\text { Guidance Counselor }\end{array}$ \\
\hline Participant 1 & Male & 46 & 24
\end{tabular}




\begin{tabular}{lccc} 
Participant 2 & Female & 50 & 29 \\
Participant 3 & Male & 45 & 19 \\
Participant 4 & Female & 41 & 15 \\
Participant 5 & Male & 38 & 14 \\
Participant 6 & Male & 26 & 6 \\
Participant 7 & Female & 36 & 3 \\
\hline
\end{tabular}

\section{Data Collection Techniques}

Before the study was conducted, the researchers sought permission from the school administrators and the participants. After securing the approval to conduct the study, the participants were oriented on the purpose of the study. It was emphasized to them that their participation is voluntary and their responses will not affect their status or performance. Their names would be mentioned including the school where the study was conducted. They were observed, interviewed and a series of meetings was held in the last five months.

\section{Research Instruments}

Three experts who are professors in guidance and counseling were asked to validate the interview questions. Their comments were gathered and the questions were finalized. The dean of the office of the student affairs in a state university was asked to give the final comments before testing it to a group of guidance counselors. Having received the approval of the dean on the questions, a pilot test was conducted to three guidance counselors from the state university through google classroom. After the focus group discussion, the guidance counselors said that the questions will be very helpful to gather the data needed in the study. The following questions were asked: (1) What did you anticipate as challenges in counseling in the new normal? (2) In providing counseling to students in the online learning modality, how did you prepare? (3) What activities have you conducted to make the students mentally and emotionally healthy in online learning? (4) In your counseling sessions with the students, what do you consider as the top three issues of students in online learning ? How did you handle them? (5) Have you applied new counseling strategies to address the issues ? Describe the strategy. (6) After almost two terms of providing counseling service to the students, what are your most important realizations ? (7) Based on your experience in counseling students (face-to-face and virtual), what activities or initiatives should be taken that will enhance the guidance and counseling program ?

\section{Data Analysis}

In analyzing the data, they were organized, categorized and labeled by the researchers. The data from the focus group discussions and interviews were coded and organized based on the themes that emerged from the workshops. Coding is the process of organizing the data by bracketing chunks (or text or image) and writing a word representing a category in the margins. It involves taking text data or pictures gathered during the data collection, segmenting sentenced (or paragraphs) or images into categories and labeling those categories with a term, often a term based in the actual language of the participants. The use of the coding process generates a description of the setting or people, as well as categories or themes for analysis (Creswell, 2014). The data that were collected from the focus group discussion including the learning continuity plan and guidance program were triangulated.

\section{RESULTS AND DISCUSSION}

The study found out that the guidance counselors considered the online modality for teaching and learning as an unchartered territory where the guidance and counseling 
program will be challenged. However, when school year 2019-2020 physical classes were abrupted due to the imposition of lockdown and the last three months of classes were conducted in different online modalities, it gave the guidance counselors a glimpse on what happens in online learning. As they were assisting the teachers in following up and addressing the concerns of the students, they gained insights on what can be done in terms of providing counseling and other guidance related services to the students. Three months before the start of school year 2020-2021, they planned and prepared their program based on their experiences and discussions. Different challenges were met in providing counseling to students despite the preparations. However, it gave them new insights and realizations which will be valuable in enhancing the guidance and counseling program of the school.

\section{Results}

\section{Preparations for Counseling in the New Normal}

Every year, academic teaching and non-teaching personnel prepare for the coming school year. Obviously, the preparations are based on students coming to school for face-to-face classes. It was unimaginable that classes will be conducted virtually until the Covid-19 pandemic forced everyone to stay home. Armed with a three-month experience in online teaching, the guidance counselors prepared by identifying the possible challenges in providing guidance services particularly counseling to students. A study revealed that this terrible time of fate has taught us that everything is unpredictable and we need to be ready to face challenges. Although this outbreak did not give us much time to plan we should take a lesson from this that planning is the key. We should plan everything, no matter if plan A fails, we should have plan B ready. This can only be done if we do scenario planning. There is a need to prioritize all the critical and challenging situations which may occur and plan accordingly (Dhawan, 2020).

Table 2 shows the potential challenges identified by the guidance counselors vis-à-vis their preparations for the new normal in education.

Table 2. Guidance Counselors Preparations on Potential Challenges in Online Learning

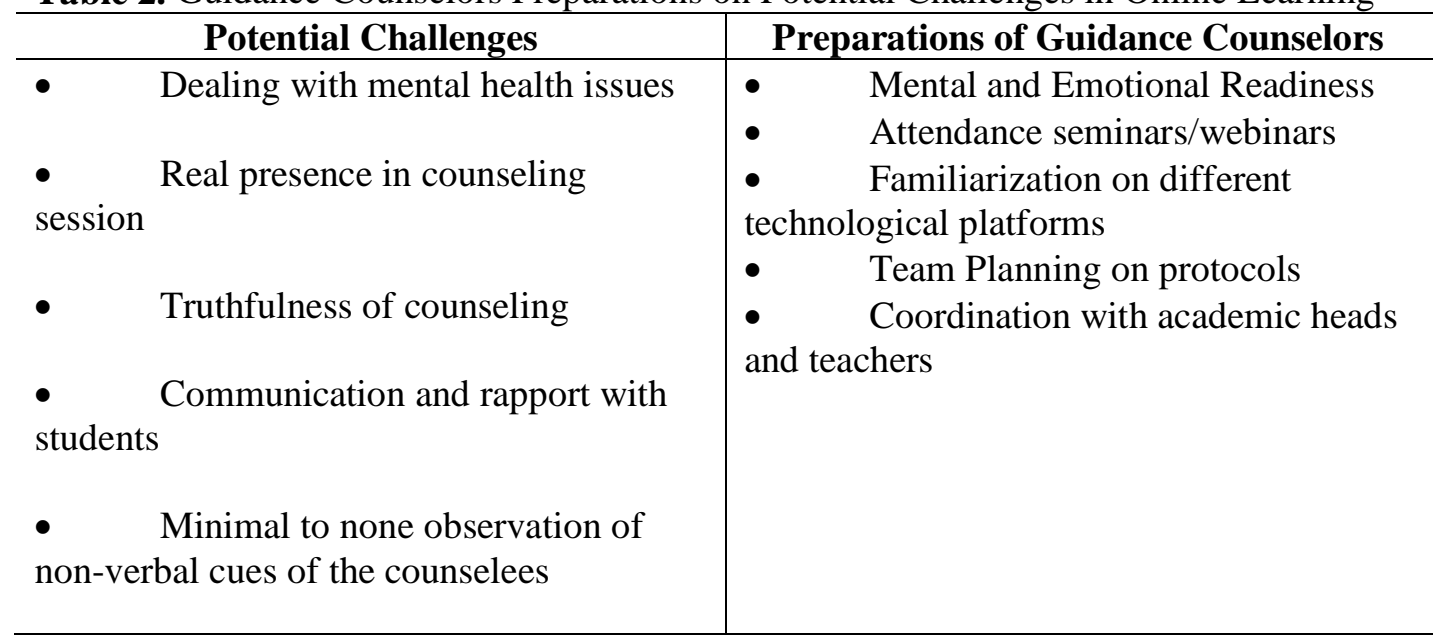

\section{Discussion}

Based on their experience in face-to-face classes in the last two years, they anticipated that mental health will be their primary concern in online classes. The rise in mental health related issues among teenagers has been significant and may continue when they 
are just at home. A study on the mental health of students during the enhanced community quarantine revealed that majority of the students displayed anxiety during the entire period of lockdown. They were worried about food and financial resources (Baloran, 2020). A guidance counselor from the senior high school department shared :

\section{"I think that there will be a sudden rise of cases related to feeling of isolation, academic stress and feeling of confinement. The real presence of a counselor, friend, or classmate will be missed by the students, and they will feel alone throughout the school year."}

In dealing with students who will experience anxiety and depression, they said that their first preparation is to be mentally and emotionally healthy and ready. They cannot assist and guide their students if they themselves are not fit to provide counseling and other guidance-related activities. As human as they are, they may experience burnout, online fatigue, and emotional stress as they help the students. A study revealed that educating for mindfulness strategies, self-awareness, and communication skills also may be helpful for school counselors. Providing a supportive environment and acknowledging school counselors' work may help them increase their sense of matter in their workplace (Kim \& Lambie, 2018).

Not knowing what may exactly work in online education specifically counseling, guidance counselors attended webinars and group discussions to equip themselves with strategies and techniques that may possibly be effective in virtual counseling. Being just an add-on to face-to-face counseling before, online counseling will now be the primary modality for assisting students. A guidance counselor from the junior high school department said that :

\section{"I decided to attend webinars provided by the Philippine Guidance and Counseling Association particularly on the current trends in counseling and mental health in the pandemic. I was able to connect and interact who were experiencing the same predicament in counseling in the new normal. It gave me the confidence to plan and face the future realities of the new normal."}

Their attendance to webinars and other online trainings allowed them to dissect more practically the possible communication concerns with students. They are worried about the authenticity of counseling in an online modality due to lack of complete observable non-verbal actions. The webinars provided them more insights and creative ways on how to approach various issues that students may experience.

As a team, the guidance counselors planned carefully their services and activities to address the anticipated challenges in online modality. Aside from the mental health issues, they are also concerned on their communication and rapport with students including the minimal to none observation of non-verbal cues of the counselees. A guidance counselor from the junior high school department pointed out that :

"The major challenge is the effectiveness of the counseling process in terms of our "presence" in communicating and dealing with our counselees. We cannot basically observe non-verbal cues. They may not feel our sincerity through a kind and warm tap on their shoulders because we are on online."

This is similar in a study conducted on the experience of online counseling. It revealed that in any system, there are tethering issues and online counseling is no exception. From the study, student-clients mentioned several obstacles to online counseling, some of 
which are poor network, which is a major obstacle; lack of trust on the part of the client; and lack of non-verbal cues. These obstacles if addressed properly will make online counseling more successful and enjoyable. If not, students will stick to only face-to-face counseling and those who cannot, will resort to other means of solving their issues of which some may be detrimental (Amos, Bedu-Addo \& Antwi, 2020).

They prepared for these concerns by creating protocols and coordinating with the department heads. Homeroom and guidance period was included in the schedule of synchronous classes. This is supported by a study that a school leadership team can be impactful. Using this process, school counselors can lead efforts within their schools to create positive impacts for students. Through the development of shared goals and shared decision-making, use of the evidence-based school counseling model and participating in a school leadership team, a school counselor can utilize evidence-based interventions to run a comprehensive school counseling program that more effectively meets the needs of all students (Geiger \& Oehrtman, 2020). They become directly part of every department where they will be attending regularly meetings with class advisers, teachers, and if needed, management team meetings. Knowing the limitations of online learning, they have to be provided by the teachers' information about the student's behavior in classes and their online activities. The guidance counselors admitted that they cannot do it alone particularly in a virtual environment.

Lastly, the guidance counselors said that one of their practical preparations is their familiarization with the online environment particularly online platforms that will be helpful in carrying out their services. Individually, they watched "Youtube" videos about google classroom, MS teams, and zoom. As a group, they shared their knowledge and skills to each other, and mentored those who were having difficulty adapting to technology though most of them have an average computer and technological skills. A study recommended that for in-service teacher training and support, it is recommended to create "unstructured professional development (e.g., mentoring or online forums)" and socially connected, learner-centered activities that allow educators to develop knowledge and skills to help them teach with technology in any format or situation, including online, remote, or blended settings (Trust \& Whalen, 2020). Aside from skills, they also had to ensure that they have laptops or desktops with good internet connection. Without these, all their plans and other preparations will be useless. A guidance counselor said that :

"I also prepared by providing the necessary tools and gadgets to prepare myself in online learning. I bought a new laptop, updated my mobile phone, and upgraded my connectivity to be 24/7 connected."

Knowing the possible challenges in online teaching and learning, the guidance counselors were able to prepare accordingly for the new normal. They felt confident and ready before the start of school year 2020-2021 but still anxious on what may eventually unfold for everything is so fluid.

\section{Results}

\section{Challenges in Counseling and Interventions in the New Normal}

As expected, counseling was challenging in the new normal. This is also the experience of guidance counselors in Indonesia. The study showed that school counselors during the Covid-19 pandemic had challenges in implementing online counselling with individual counseling services and group counseling services. The implementation of counseling services for students by school counselors uses technology media as an element of developing the professional competence of school counsellors. Professional guidance and 
counseling teachers can plan, implement, and evaluate themselves in the use of technology media in counseling services (Supriyanto et al., 2020). The concerns of the students had to be managed and address in order to keep them mentally and emotionally healthy in their online classes. No stone should be left unturned even in the online learning modality. Thus, counseling challenges begin when student's problems surface. Guidance counselors must attend to the concerns and find the right strategies to address them. Various interventions will help manage the challenges and address the students concerns eventually. It can be gleaned in Table 3 the students' concerns, the counseling challenges of guidance counselors, and interventions conducted to address the concerns.

Table 3. Students' Concerns, Counseling Challenges and Interventions

\begin{tabular}{|c|c|c|}
\hline Students' Concerns & Counseling Challenges & Interventions \\
\hline 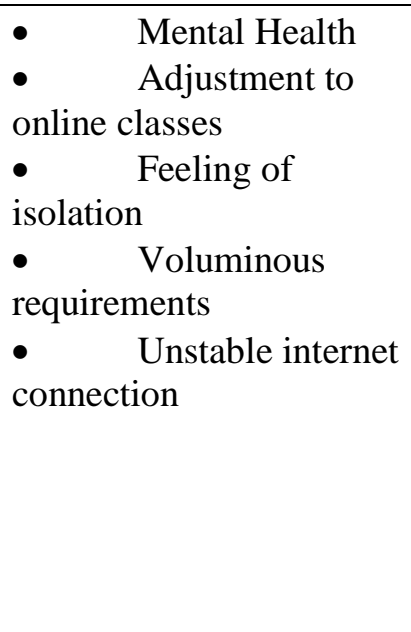 & $\begin{array}{l}\text { - Availability of } \\
\text { students for counseling } \\
\text { - } \quad \text { Motivating students } \\
\text { to study and participate } \\
\text { - Online availability of } \\
\text { counselors (24/7) } \\
\text { - Real presence in } \\
\text { counseling } \\
\text { - Unstable internet } \\
\text { connection }\end{array}$ & $\begin{array}{l}\text { - Homeroom and } \\
\text { Guidance Class } \\
\text { - Online Counseling } \\
\text { (Group and Individual) } \\
\text { - Meeting with class } \\
\text { advisers and academic heads } \\
\text { - Mental Health } \\
\text { Awareness Activities } \\
\text { - Classroom Visits } \\
\text { - Communication with } \\
\text { Parents }\end{array}$ \\
\hline
\end{tabular}

\section{Discussion}

In their counseling sessions with the students, the guidance counselors unsurprisingly shared that mental health is the top concern of the students in online learning. Having anticipated it, they made it a point to be available when students reach out to them for help. In Japan, the suicide and mental health during the Covid-19 pandemic notably increased. A study found out and recommended that continuous monitoring of mental health, particularly that of the most vulnerable populations, and appropriate suicide prevention efforts are necessary during and in the aftermath of the COVID-19 pandemic (Ueda \& Matsubayashi, 2020). As more students experience mental health concerns, from anxiety to depression, online fatigue and physical exhaustion began creeping in on the counselors. Students might be at higher risk of social isolation and the development of mental health problems during the COVID-19 crisis. In particular, when they live by themselves, have less direct contact to close family members and friends, receive less social support, and have a weaker integration in the social networks of students (Elmer, Mepham, \& Stadtfeld, 2020). However, their regular meeting with the class advisers and selected academic heads proved to be very helpful in handling the students' mental health problems. The homeroom and guidance program and adviser's class period helped in addressing students' anxiety and depression. Conducting group counseling is also an appropriate strategy to assist the students. A guidance counselor from the grade school department shared that :

"Our close coordination with parents and teachers to monitor and guide the students helped a lot. The regular online sessions with students became 
a venue for them express their thoughts and feelings."

Being at home and feeling isolated came out as an issue among students who are used to interacting with classmates and friends in school. In doing school requirements and expressing their feelings, they felt that they are alone and online communication appears to be unreal. To lessen their feeling of isolation, the homeroom and guidance program is a venue where they share their experiences and feelings. Nothing related to academic requirements is discussed. It is a challenge for guidance counselors to make the students feel that they are not alone in this online journey. The class advisers help them by being available for consultation and advice. The close coordination between guidance counselors and class advisers make the students feel that they are taken cared of. A junior high school guidance counselor shared that :

"I did basic counseling and more synchronous Homeroom Guidance Period.

I instructed the students to open their cameras while we talk, so that there would be more interaction between us. The pandemic has taught us to be impersonal as we are confined and isolated in our places, work/school and home. By opening our cameras and seeing our facial expressions, we can minimize the impersonal effect of online counseling and online learning in general."

Another issue that challenged the guidance counselors is the plenty of requirements that students have to accomplish. They complained about the difficulty of accomplishing them on time not to mention the level of difficulty of the requirements. A study revealed that the types and the number of tasks contributed to the problems within online classes. The students perceived the extra burden due to the big number of assignments which came at the same time and for some of them writing essay and making video then uploading it in YouTube were quite challenging especially with the short deadline (Agustina, Matra \& Karimah, 2020). Despite proving to be the most effective alternative to traditional learning during this lockdown, online learning has been acknowledged to be a major source of mental health issues among students. The lack of interaction with peers, for instance, is a significant aspect that has affected the ability of the students to experience the optimal benefits of online learning. It is undeniable that the ability to interact with peers and the instructor in the traditional classroom environment cannot be replicated in an online environment despite the offerings of interactive platforms like zoom, skype and google meet (Akpinar, 2021). The guidance counselors discussed the concerns with the class advisers and management team which resulted to the lessening of requirements in Term 2. Motivating the students to study was challenging but the regular classroom visits, coordination with teachers, and meeting with the management team proved to be the appropriate interventions for this concern. A guidance counselor said that:

"The students had difficulty focusing on the different tasks that they have to accomplish. It caused them anxiety due to school requirements and felt fed up by just staying at home. I handled these issues and problems through constant follow up and encouragement. I made myself available to them through hangouts and messenger in that way it assures them that we will be journeying together in this mode of education."

Students may not be motivated to study and learn in an online setting. In fact, a study showed that the students' inability to maintain their motivation in learning is a concern. The lack of interest might be due to the absence of intrinsic and extrinsic motivation, the drive which pushed them to keep learning. At the same time, the finding also suggests the lecturers' lack of capability in motivating the students (Agustina, Matra \& Karimah, 2020). 
Another issue is about the unstable internet connection. Both students and guidance counselors experienced internet connection problems that prevented them from fulfilling their duties and responsibilities. Knowing that this is a common problem in the Philippines, constant communication through other modalities like text messaging or calls enable them to inform all those concerned on the technical difficulties encountered by the students and guidance counselors. Through close coordination with the teachers and academic heads, this is resolved. Moreover, the spirit of understanding and compassion is permeating in the school community. A study on online learning revealed that poor Internet connection was evident in all cases, thus producing poor interactions among the students. The professors tried to understand the situations and gave them time to read the uploaded materials (Reyes-Chua et al., 2020). A similar study revealed that some perceived challenges on the delivery of distance learning, and the number one on the list is internet connection/ connectivity (Asio \& Bayucca, 2021).

A study found out that accessibility, convenience, privacy, and mobility were some significant benefits they indicated concerning online counseling. On the contrary, loss of non-verbal cues, mistrust, and poor internet connectivity were their major obstacles to online counseling (Amos, Bedu-Addo, \& Antwi, 2020). Despite the issues and challenges encountered by the students and teachers, appropriate interventions were provided in collaboration with the academic heads, class advisers and subject teachers. Various activities helped managed and addressed the concerns of the students in online learning.

\section{Results}

Realizations and Inputs for an Enhanced Guidance and Counseling Program

The online modality for teaching and learning for school year 2020-2021 allowed the guidance counselors to experience new things in guidance and counseling that led to personal realizations. Their realizations triggered them to try new strategies and activities which can be included in the development of an enhanced guidance and counseling program. Table 4 shows the realizations of the guidance counselors and their suggested inputs for next year's program.

Table 4. Realizations and Inputs to Guidance and Counseling Program

\begin{tabular}{l|l}
\hline \multicolumn{1}{c|}{ Realizations } & \multicolumn{1}{c}{ Inputs to Guidance and Counseling } \\
Program
\end{tabular}

\section{Discussion}

Whether face-to-face or online, communication will always be the key. However, guidance counselors have to be patient and alert in communicating with students. Their communication lines are always open because anything can happen in an online 
environment. Based on their experience, parents should always check their children for updates by opening their email or replying to calls or texts. Likewise, all contact information should be updated. They also have to revitalize their orientation program for parents and students that will emphasize the key points in providing assistance for mental and emotional health concerns.

In terms of communication with the academic heads, class advisers, and teachers, they realized that everyone is more open and participative in assisting each other for the betterment of the students. They are able to present and discuss the issues and concerns of students with the teachers particularly the class advisers leading to an appropriate intervention. Because of this, collaboration is stronger and counseling becomes more effective. Schools with strong principal-counselor collaboration have lower turnover, higher job satisfaction, and more effective school counseling programs. Not only a benefit to the relationship of the principal and counselor, such collaboration is also beneficial to students, staff, and the school as a whole McConnell et al, 2020). Cooperation must be exhibited in the degree of active interest, mutual help, and collaboration among teachers, counselors, and administrators (Lunenberg, 2010). The guidance and counseling program should include a renewed protocol and better communication system. A guidance counselor pointed out that :

"Communication should involve everyone in the education system, from the principal to the middle managers, teachers, guidance counselors, students, parents/guardians. This approach will provide different perspectives on the totality of online learning."

With the experience in online modality, they realized that technology is here to stay and will always be important in the education of the young. Whether they like it or not, they have to optimize technology in the delivery of their services particularly counseling. Technology will play a big role in counseling even when face-to-face classes resume. Digital literacy needs to be maximized to teachers counselors can be more innovative in the digital age. the majority of respondents are digital users, and their levels of digital are communication and collaboration, several respondents are a content creator. If the school counselor is unusual to create guidance and counseling content program, from various information on the internet, it is impossible to be able to create innovative programs. Critical thinking and creativity can improve innovation through digital literacy. Combinatorial innovation is a form of innovation that emerges from digital literacy. Developmental attempt for digital literacy and innovation skill i.e. workshop on the use of ICT, equalization of perceptions about the features of the latest digital applications, and the use of design thinking become a medium for mapping literacy outcome (Suryahadikusumah, \& Nadya, 2020). A guidance counselor intimated that :

\section{"Technology helps a lot and we have to learn how to adapt."}

During the outbreak in Indonesia, several practitioners such as counselors, psychiatrists, psychologists, therapists, and social workers have developed their own initiatives to help with psychological first aid and to improve the general psychological state of the community, including addressing high stress levels, anxiety, depression, OCD, and other psychological conditions. The forms of intervention are done through online counseling, distribution of brochures on the prevention of the disease, websites, YouTube video tutorials, videos, short movies, online discussions through WhatsApp groups, and other means (Ifdil et al., 2020).

Aside from technology, they realized also that they have to be creative and innovative in counseling the students. But it does not mean that they have to find new things and 
discover new theories. They said that their creativity and innovation start by going back to the basics of counseling. It is the heart of the guidance program. They have to renew their interest by reviewing the basics and true meaning of counseling. Having accepted the limitations of online counseling, they will also be able to compensate for this by reunderstanding the meaning of counseling and determine how online counseling can be provided more effectively. Attendance to relevant trainings and conferences will bring new ideas and give them more confidence in planning and conceptualizing their activities. This is in consonance on how future counselors are trained. A study found out that the future direction of the counseling profession that has implications for both educational environments is the formal integration of technology skills training into the curriculum. While the academic core content areas are aligned for both settings, telehealth is rapidly changing the required skill sets for counselors to include communicating, documenting, and billing clients through electronic means (Haddock, Cannon \& Grey, 2020). Another study revealed that with the online modality in teaching and learning including counseling, counselors need greater support in the transitional experience. They explained that support began within the counselor educator, as resistance to online teaching could limit personal growth in the changing academic landscape. Moreover, they desired greater support on the professional level to align counselor education standards with professional practice in the field. They also wanted greater institutional support (Hale \& Bridges, 2020).

Regardless of the modality of education, guidance and counseling will always be an integral part in the holistic formation of students. It is important that the program is responsive to any kind of situation. Guidance and counseling services have emerged as the much required in the current scenario. For helping students deal with the problems of education, employment, etc. during these trying times of COVID-19 pandemic, teachers need to don the hat of a counselor too. They should provide psychological first aid to the students in case of any emergency. Parents should also help the children and coordinate with the teachers in maintaining the optimism around them and maintain a cordial relationship with their children. In this challenging time, there is a need to provide emotional support to the students so that they can come out of this challenge triumphantly without harming their mental well-being. And that is the most significant achievement for a teacher to bring back the class, after the pandemic, mentally healthy and sound. It is essential to remove anxiety and mental pressure of students so that they can concentrate more on their studies and make them healthy and joyful during lockdown. Online counseling session should be provided including regular monitoring to help them cope with these problems (Kant, 2020).

\section{CONCLUSIONS}

The study found out that the guidance counselors anticipated correctly the issues and concerns of students in online teaching and learning. Their preparations were able to address the needs of the students. However, more issues and concerns including challenges in counseling came out. Being in the real online teaching and learning is far different from what they anticipated it would be. Applying various strategies and approaches, they were able to provide appropriate interventions to students' issues and concerns. Their experiences led to meaningful realizations and insights that will be valuable in the development of the guidance and counseling program for school year 2021-2022. It can be concluded that online counseling is not easy and has a lot of limitations that include establishing real presence and sincerity in counseling. Dealing with mental health concerns in an online modality is definitely challenging and guidance counselors can only do as much in order to handle it. The homeroom and guidance period, advisers time, open and stronger communication and collaboration with the 
academic heads, class advisers, and teachers helped a lot in providing counseling and guidance to the students. New approaches and strategies in counseling can only be discovered if the basics of counseling are properly understood and followed. The counseling challenges can be overwhelming but overcoming them is very much possible with the cooperation and assistance of all stakeholders.

\section{REFERENCES}

Agustina, D., Matra, S. D., \& Karimah, S. (2020). CHALLENGES OF HAVING ONLINE LEARNING ACTIVITIES: UNIVERSITY STUDENTS'PERSPECTIVES. The International English Language Teachers and Lecturers Conference.

Akpinar, E. (2021). The Effect of Online Learning on Tertiary Level Students' Mental Health during the Covid19 Lockdown. The European Journal of Social \& Behavioural Sciences, 30(1), 3300-3310.

Ahmed, A., \& Firdous, H. (2020). The Transformational Effects of COVID-19 Pandemic on Guidance and Counseling. International Journal of Advance Research and Innovative Ideas in Education. Vol-6 Issue-6. ISSN (O)-2395, 4396.

Amos, P. M., Bedu-Addo, P. K. A., \& Antwi, T. (2020). Experiences of Online Counseling Among Undergraduates in Some Ghanaian Universities. SAGE Open, 10(3), 2158244020941844.

Asio, J. M. R., \& Bayucca, S. A. (2021). Spearheading education during the COVID-19 rife: Administrators' level of digital competence and schools' readiness on distance learning. Journal of Pedagogical Sociology and Psychology, 3(1), 19-26. https://doi.org/10.33902/JPSP.2021364728

Baloran, E.T. (2020). Knowledge, Attitudes, Anxiety, and Coping Strategies of Students during COVID-19 Pandemic, Journal of Loss and Trauma, 25:8, 635-642.

DOI: $10.1080 / 15325024.2020 .1769300$

Callo, E. and Yazon, A. (2020). "Exploring the Factors Influencing the Readiness of Faculty and Students on Online Teaching and Learning as an Alternative Delivery Mode for the New Normal," Universal Journal of Educational Research, Vol. 8, No. 8, pp. 3509 - 3518, 2020. DOI: 10.13189/ujer.2020.080826.

Creswell, J. W. (2014). Research Design $4^{\text {th }}$ edition. Los Angeles: Sage Publications Inc. Department of Education Order No. 007 s. 2020 (Philippines). School Calendar and Activities for School Year 2020-2021. May 11,2020.

Department of Education Order No. 12 s. 2020 (Philippines). Adoption of the Basic Education Learning Continuity Plan For School Year 2020-2021 in Light of the COVID19 Public Health Emergency. June 19,2020.

Dhawan, S. (2020). Online learning: A panacea in the time of COVID-19 crisis. Journal of Educational Technology Systems, 49(1), 5-22.

Elmer, T., Mepham, K., \& Stadtfeld, C. (2020). Students under lockdown: Comparisons of students' social networks and mental health before and during the COVID-19 crisis in Switzerland. Plos one, 15(7), e0236337.

Geiger, S. N., \& Oehrtman, J. P. (2020). School Counselors and the School Leadership Team. Professional School Counseling, 23(1_part_3), 2156759X2090356. doi:10.1177/2156759x20903566 
Haddock, L., Cannon, K., \& Grey, E. (2020). A Comparative Analysis of Traditional and Online Counselor Training Program Delivery and Instruction. Professional Counselor, 10(1), 92-105.

Hale, N., \& Bridges, C. W. (2020). The Experiences of Counselor Educators Transitioning to Online Teaching. Journal of Educational Research and Practice, 10(1), 10.

Ifdil, I., Fadli, R. P., Suranata, K., Zola, N., \& Ardi, Z. (2020). Online mental health services in Indonesia during the COVID-19 outbreak. Asian journal of psychiatry.

Kant, R. (2020). Covid-19 Pandemic: Looking in the mind of students during lockdown. Purakala. UGC CARE J, 31, 508-522.

Kim, N., \& Lambie, G. W. (2018). Burnout and Implications for Professional School Counselors. Professional Counselor, 8(3), 277-294.

Lunenburg, F. C. (2010). School guidance and counseling services. Schooling, 1(1), 1-9.

McConnell, K. R., Geesa, R. L., Mayes, R. D., \& Elam, N. P. (2020). Improving School Counselor Efficacy Through Principal-Counselor Collaboration: A Comprehensive Literature Review. Mid-Western Educational Researcher, 32(2).

Neyland-Brown, L., Francis, J. D., \& Burns, G. (2019). Role Responsibilities, Time Commitments, and Counseling Activities of Ohio Licensed School Counselors. Journal of Counselor Practice, 10(1), 1-18.

Pastor, C. K. L. (2020). Sentiment analysis on synchronous online delivery of instruction due to extreme community quarantine in the Philippines caused by COVID-19 pandemic. Asian Journal of Multidisciplinary Studies, 3(1), 1-6.

Reyes-Chua, E., Sibbaluca, B. G., Miranda, R. D., Palmario, G. B., Moreno, R. P., \& Solon, J. P. (2020). The status of the implementation of the e-learning classroom in selected higher education institutions in region IV-A amidst the covid-19 crisis. Journal of Critical Reviews, 7(11), 253-258.

Supriyanto, A., Hartini, S., Irdasari, W. N., Miftahul, A., Oktapiana, S., \& Mumpuni, S. D. (2020). Teacher professional quality: Counselling services with technology in Pandemic Covid-19. Counsellia: Jurnal Bimbingan dan Konseling, 10(2), 176-189.

DOI: http://doi.org/10.25273/counsellia.v10i2.7768

Suryahadikusumah, A. R., \& Nadya, A. (2020, August). Digital Literacy and Innovation for Guidance and Counseling Program. In 2nd International Seminar on Guidance and Counseling 2019 (ISGC 2019) (pp. 190-195). Atlantis Press.

Trust, T. \& Whalen, J. (2020). Should Teachers be Trained in Emergency Remote Teaching? Lessons Learned from the COVID-19 Pandemic. Journal of Technology and Teacher Education, 28(2), 189-199. Waynesville, NC USA: Society for Information Technology \& Teacher Education.

Ueda, M., Nordström, R., \& Matsubayashi, T. (2020). Suicide and mental health during the COVID-19 pandemic in Japan. medRxiv. 
Villarreal-Davis, C., Sartor, T. A., \& McLean, L. (2020). Utilizing Creativity to Foster Connection in Online Counseling Supervision. Journal of Creativity in Mental Health, 114.

Wong, K. P., Bonn, G., Tam, C. L., \& Wong, C. P. (2018). Preferences for online and/or face-to-face counseling among university students in Malaysia. Frontiers in psychology, 9, 64 . 